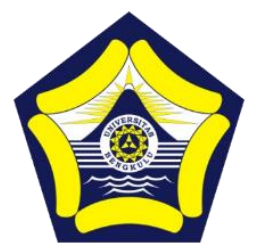

\title{
Development of E-Module Based on Morphometric Studies of the Diversity of Sumatran Turtles for High School Students
}

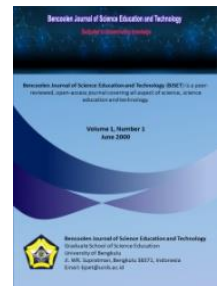

\author{
Fitri Dayeni*, Aceng Ruyani and Hery Suhartoyo \\ Graduate School of Science Education, University of Bengkulu \\ *Email: fitridayeni64@gmail.com
}

DOI: https://doi.org/10.33369/bjset.1.2.61-68

\begin{abstract}
This study aims to determine the morphometry of Sumatran turtles in the conservation area of the Turtle Learning Center (TLC), Bengkulu University and the Ruyani Life Science Learning Resource (SBIH), then the results of this morphometric study are made into E-Module products. This type of study is a Research and Development (R\&D). Data collection techniques were performed in the form of observation and documentation. The data analysis technique used a qualitative descriptive technique, namely the data obtained and then analyzed descriptively. Morphometric data were analyzed using qualitative descriptive. Furthermore, the product is made in the form of an E-Module. Research results of Morphometric studies in TLC contained five types of Sumatran turtles, namely Cuora amboinensis, Heosemys spinosa, Cyclemys dentata, Siebenrockiella crassicollis, and Manouria emys. In SBIH Ruyani, there are four types of Sumatran turtles, namely Dogania subplana, Pelochelys cantorii and Orlitia borneensis. The results of the E-Module product for the morphometric study of the Sumatran turtles after validated by the expert obtained a very decent assessment presentation. The material expert validator obtained an assessment presentation of $86.53 \%$, and the media expert obtained an assessment percentage of $91.67 \%$.
\end{abstract}

Keywords: Morphometric Study, Sumatran Turtles, Module.

\section{INTRODUCTION}

Indonesia is one of the richest countries in the world in terms of biodiversity. Islands in Indonesia are able to accommodate around $12-13 \%$ of all biodiversity in the world, but at this time the level of biodiversity in Indonesia is starting to decline due to environmental pollution, illegal trade, and so on. This will cause a species to be vulnerable or endangered. To maintain the existence of these species, Indonesia needs knowledge that can protect and maintain the diversity of natural resources from one generation to the next. Besides being protected, it should also be used as an object and natural tourism destination (Iskandar, 2000).

Conservation education is a program that aims to provide knowledge to many people to be more aware and more concerned about preserving the environment. protect, and use biological resources wisely and sustainably. Conservation education programs can be held in various forms, including through formal and non-formal education (Zukmadini, 2017). Conservation is an effort or action to maintain the existence of something continuously in quality or quantity. Conservation is the concept of the process of managing a place or space or object so that the cultural meaning 
contained therein is well preserved (Ministry of Forestry, 2012). According to Melati (2012) Conservation is the maintenance and protection of something regularly to prevent damage or extinction. Meanwhile, according to the Big Indonesian Dictionary, Natural Resources Conservation is the management of natural resources (living) by using them wisely and ensuring continuity of supply while maintaining and increasing the quality of their value and diversity.

Turtles are reptiles that are easily recognized because of the carapace that wraps around their body, which acts as a shield against enemy threats and only its legs, head and tail stand out (Kursini, 2015). Currently tortoise is an export commodity that promises marketing opportunities for exporters. The benefits of turtles and their high price make the survival of the tortoise even more threatened. The export activities of turtles to European countries, China, Japan and Hong Kong occur because of their many uses. Tortoise meat and eggs are used as food ingredients and the kerapak is processed into flour for cosmetic raw materials.

Iskandar (2000) explained that the factors that are threatened with extinction of turtles are due to the relatively small number of individuals and the wide distribution area, which causes the frequency of encounters between individuals to be relatively rare. This makes the possibility of marriage quite rare. The slow growth of turtles is another factor in threatening the number of turtles in Indonesia. The role of turtles in the ecosystem, namely turtles are among the most abundant vertebrate animals, in the environment most of these animals play a very large role in ecosystem function. Turtles eat plants and store seeds in their feces, then flower seeds, then turtle eggs are the main food source for animals, such as mice, snakes and lizards. This ecologically also plays a role in maintaining the balance of ecosystems in nature.

However, most people do not know about it, given the important role of turtles in nature, the researchers want to conduct research on the Morphometric Study of the diversity of species of Sumatran turtles. This information will be developed in the form of E-Learning media in the form of E-Modules. Module is one of the teaching materials that is packaged in a comprehensive and systematic manner, which contains a set of learning experiences that are planned and designed to help students master specific learning goals (Daryanto, 2013).

Modules are learning tools or tools that contain materials, methods, limitations in learning materials, instructions for learning activities, exercises and ways of evaluating which are designed systematically and attractively to achieve the expected competencies and can be used independently. The use of modules does not depend on other media, provides opportunities for students to practice and provide summaries, provides opportunities for self-tests, and accommodates students' difficulties by providing follow-up and feedback (Khoyati, 2016).

The E-Module was chosen in the hope that students can learn independently using the Emodule that has been developed which contains information about the conservation of Sumatran turtles so that students can cultivate a love for endangered animals, and not exploit excessively.

\section{RESEARCH METHODS}

This research was conducted from February to August 2020, located at Bengkulu University, SBIH Ruyani and SMAN 1 (High School) in Bengkulu City. The type of research was Research and Development (R\&D). Data collection techniques were in the form of observation and documentation. The measurement technique was adopted from Kendrick and Ades (2009). The data analysis technique used a qualitative descriptive technique. Morphometric data were analyzed using qualitative descriptive. Furthermore, the product was made in the form of E-Module.

\section{RESULTS AND DISCUSSION}


There are 5 types of Sumatran turtles in Bengkulu University TLC, namely Cuora amboinensis, Heosemys spinosa, Cyclemys dentata, Siebenrockiella crassicollis, dan Manouria emys. And in SBIH Ruyani there are 4 types of Sumatran turtles, namely Dogania subplana, pelochelys cantorii and orlitia borneensis. The results of the identification of morphometric measurements that have been carried out are shown in Table 1.

Table 1. Morphometric Measurements for Sumatran Turtles

\begin{tabular}{|c|c|c|c|c|c|c|c|c|c|}
\hline \multirow[b]{2}{*}{ No } & \multirow[b]{2}{*}{ Name } & \multirow[b]{2}{*}{$\mathrm{JK}$} & \multirow[b]{2}{*}{$\begin{array}{l}\mathrm{BB} \\
(\mathrm{Kg})\end{array}$} & \multirow[b]{2}{*}{$\begin{array}{l}\text { PK } \\
(\mathrm{cm})\end{array}$} & \multicolumn{2}{|c|}{ Carapace } & \multicolumn{2}{|c|}{ Plastron } & \multirow[b]{2}{*}{$\begin{array}{l}\mathrm{PE} \\
(\mathrm{cm})\end{array}$} \\
\hline & & & & & $\begin{array}{l}\text { PLK } \\
(\mathrm{cm})\end{array}$ & $\begin{array}{l}\text { LLK } \\
(\mathrm{cm})\end{array}$ & $\begin{array}{l}\text { PLP } \\
\text { (cm) }\end{array}$ & $\begin{array}{l}\text { LLP } \\
(\mathrm{cm})\end{array}$ & \\
\hline \multirow{2}{*}{1} & \multirow{2}{*}{ Cuora amboinensis } & Jantan & 1,16 & 6 & 22 & 21 & 17,5 & 17 & 5 \\
\hline & & Betina & 1,10 & 4 & 22 & 21 & 10 & 9,5 & 3,5 \\
\hline \multirow{2}{*}{2} & \multirow{2}{*}{ Heosemys spinosa } & Jantan & 1,5 & 7 & 24 & 23 & 21 & 16 & 6 \\
\hline & & Betina & 1,4 & 6 & 22 & 21 & 19 & 13 & 3 \\
\hline \multirow{2}{*}{3} & \multirow{2}{*}{ Cyclemys dentate } & Jantan & 1,5 & 7 & 25 & 22 & 24 & 14 & 8 \\
\hline & & Betina & 1,0 & 5 & 22 & 20 & 19 & 12 & 6 \\
\hline \multirow{2}{*}{4} & \multirow{2}{*}{ Manouria emys } & Jantan & 5,07 & 9 & 49 & 40 & 44 & 39 & 7 \\
\hline & & Betina & 4,08 & 9 & 42 & 39 & 39 & 36 & 6 \\
\hline \multirow{2}{*}{5} & \multirow{2}{*}{ Pelochelys cantorii } & Jantan & 24 & 21 & 72 & 59 & 51 & 56 & 33 \\
\hline & & Betina & 10 & 21 & 47 & 35 & 42 & 40 & 30 \\
\hline \multirow{2}{*}{6} & \multirow{2}{*}{ Dogania subplana } & Jantan & 2 & 5 & 15 & 12 & 11 & 10 & 5 \\
\hline & & Betina & 0,8 & 5 & 14 & 10 & 10 & 10 & 4 \\
\hline \multirow{2}{*}{7} & \multirow{2}{*}{ Orlitia borneensis } & Jantan & 3,5 & 8 & 29 & 25 & 25 & 17 & 8 \\
\hline & & Betina & 2,8 & 7 & 24 & 22 & 21 & 16 & 6 \\
\hline \multirow{2}{*}{8} & \multirow{2}{*}{$\begin{array}{l}\text { Notochelys } \\
\text { platynota }\end{array}$} & Jantan & 1,9 & 8 & 29 & 23 & 23 & 18 & 8 \\
\hline & & Betina & 1,6 & 6 & 25 & 22 & 21 & 17 & 7 \\
\hline \multirow{2}{*}{9} & \multirow{2}{*}{$\begin{array}{c}\text { Siebenrockiella } \\
\text { crassicollis }\end{array}$} & Jantan & 0,7 & 6 & 19 & 15 & 14 & 8 & 5 \\
\hline & & Betina & 0,9 & 5 & 20 & 17 & 16 & 9 & 4 \\
\hline
\end{tabular}

Information: $\mathrm{JK}=$ Gender, PLK = Carapacic Arch Length, BW = Body Weight, LLK = Carapace Arch Width, PK = Head Length, PLP = Plastron Curve Length, PE = Tail Length, LLP = Plastron Curve Width

\section{Identification and Description of Cuora amboinensis}

Cuora amboinensis is a type of semi-aquatic turtle known as a box turtle because it is able to insert its entire body into its shell. Conservation status is appendix II sites with CITES "Vulnerable" status, Appendix I and II. Based on the morphology Cuora amboinensis has a grayish black carapace, oval and tall carapace (Fig 1a and 1c). Plastron is dirty white or cream, with large blackish patches (Figures $1 \mathrm{~b}$ and $1 \mathrm{~d}$ ).

The head is $6 \mathrm{~cm}$ male and $4 \mathrm{~cm}$ female (Table 1). The head is black with three distinctive yellow stripes: around the edges of the head above the eyes, on the cheeks and on the lips. Yellow lines also run along the edges of the legs. The tail measures $5 \mathrm{~cm}$ in male and $3.5 \mathrm{~cm}$ in female (Table 1), the limbs have webbed fingers.
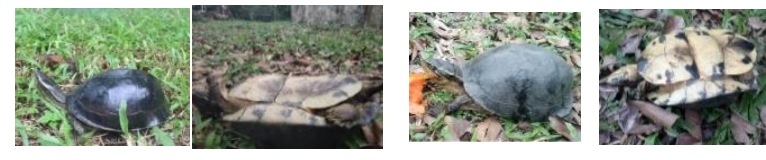

(a)
(b)
(c)
(d)

Figure 1. Cuora amboinensis: male carapace (a), male plastron (b), female carapace (c) and (d) female plastron (source: Personal documentation)

\section{Identification and Description of Heosemys spinosa}

Heosemys spinosa or known as the sun turtle is one of Indonesia's rare reptiles with a Conservation Status, namely Endangered (Threatened) in the IUCN Red List, CITES includes it in the Appendix II list. Based on the morphology of Heosemys spinosa, it has a brown carapace, serrated edges of the carapace (Figure $2 \mathrm{a}$ and $2 \mathrm{c}$ ).

These spines will disappear as they get older, the carapace is oval with a pale line to the middle of the 'keel'. The plastron is brown, with radial black stripes, the surface of the plastron is smooth (Figures $2 \mathrm{~b}$ and $2 \mathrm{~d}$ ).

The head has a length of $7 \mathrm{~cm}$ male and $6 \mathrm{~cm}$ female (Table 1), the head is blackish brown with a faint red line, the head can fit perfectly into the carapace. The tail is $6 \mathrm{~cm}$ male and $3 \mathrm{~cm}$ female (Table 1), the tail is round and slender with dominant black scales and orange spots.

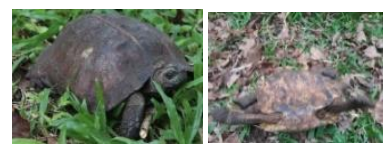

(a)

(b)

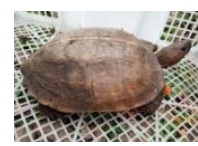

(c)

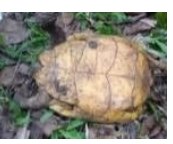

(d)

Figure 2. Heosemys spinosa: male carapace (a), male plastron (b), female carapace (c) and (d) female plastron (source: Personal documentation)

\section{Identification and Description of Cyclemys dentata}

Cyclemys dentata is a tortoise with teeth, because there are serrations on the shield. Conservation Status of Cyclemys dentata by IUCN is in the status of almost endangered / low risk, this is because Cyclemys dentata is widely traded for maintenance.

The carapace of Cyclemys dentata is yellow-brown, round in shape and tends to be flat (Figs. $3 \mathrm{a}$ and $3 \mathrm{c}$ ). The plastron can be moved, the gular discs are triangular in shape not protruding, the femoral discs are longer than the anal discs, the front edge of the pair of anal discs is arc-shaped (Setiadi, 2015).

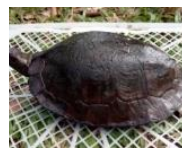

(a)

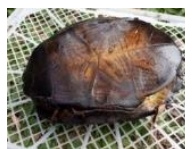

b)

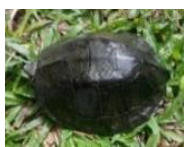

(c)

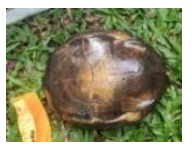

(d)

Figure 3. cyclemys dentata: male carapace (a), male plastron (b), female carapace (c) and (d) female plastron (source: Personal documentation)

The plastron pattern is black and slightly thickened stripes (Figures $3 \mathrm{~b}$ and $3 \mathrm{~d}$ ). There are longitudinal, yellowish or reddish streaks on the neck. The head has red patches or stripes that are thin and almost invisible. Head length of $7 \mathrm{~cm}$ for male and $5 \mathrm{~cm}$ for female (Table 1), tail measuring $8 \mathrm{~cm}$ for male and $6 \mathrm{~cm}$ for female (Table 1). 


\section{Identification and Description of Manouria emys}

Manouria emys is a brown tortoise known as the elephant leg tortoise, including the largest tortoise in Asia. Conservation Status Protected and Threatened with Extinction by IUCN (CITES: Appendix II). Carapace brown, high curved. The marginal strips (edges) on the front and around the hind legs are horizontal and slightly curved upwards (Figures 4a and 4c). Plastron is stained white and plain (Figures $4 \mathrm{~b}$ and $4 \mathrm{~d}$ ).

Its feet were big like those of an elephant, with fingers that were not clearly visible. The hind legs are five-toed and four-toed forelegs, tapered in shape, the scales on the legs are thickened like nails and shields. The head is blackish brown. Head length of $9 \mathrm{~cm}$ for male and $9 \mathrm{~cm}$ for female (Table 1), tail measuring $7 \mathrm{~cm}$ for male and $6 \mathrm{~cm}$ for female (Table 1).

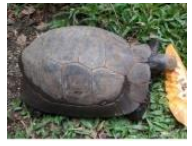

(a)

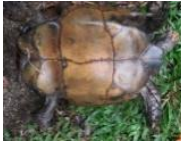

(b)

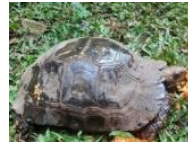

(c)

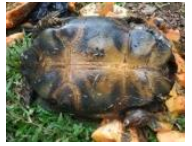

(d)

Figure 4. Manouria emys: male carapace (a), male plastron (b), female carapace (c) and (d) female plastron (source: Personal documentation)

\section{Identification and Description of Pelochelys cantorii}

Pelochelys cantorii is known as Cantor's giant Labi-turtle. According to the IUCN, CITES Conservation Status of this giant turtle turtle is endangered. And has disappeared in part of its home range (IUCN). Pelochelys cantorii has a large body size with an oval and almost spherical carapace, the carapace is gray-green (Figures 5a and 5c).

His neck was covered with sparsely scattered warts. wide head and small eyes close to the tip of the muzzle. dark mottled head, with a yellow color around the carapace. The belly shield is yellowish white (Figs. 5b and 5d).

Its mouth has relatively thick lips, its nose rests on the tip of its small trunk and short, short tail. The head and neck are gray. The feet are dull black with fully webbed toes (Table 1).

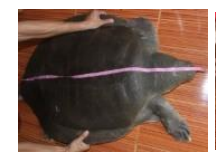

(a)

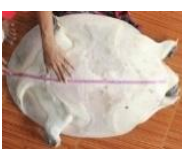

(b)

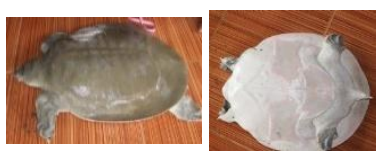

(c)

(d)

Figure 5. Pelochelys cantorii: male carapace (a), male plastron (b), female carapace (c) and (d) female plastron (source: Personal documentation)

\section{Identification and Description of Dogania subplana}

Dogania subplana or known as forest turtles. Conservation status of Dogania subplana, which is included in the CITES Appendix II and the IUCN red list or endangered species. The body shape is oval or slightly oval, flat and without scales. The carapace is blackish-gray, or brownish in color with fine patterns or spots (Figs. 6a and 6c). the stomach or soft plastron is gray black and the underside yellowish (Figs. 6b and 6d).

From the tip of the muzzle there are black stripes extending towards the neck. The toes of the front and back feet are fully webbed and each foot has three claws. The tail is relatively short, the nose is tipped like a trunk which is short and small. 


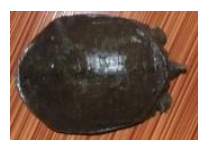

(a)

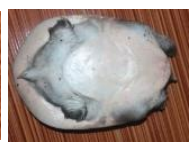

(b)

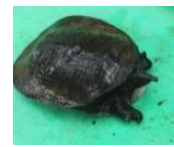

(c)

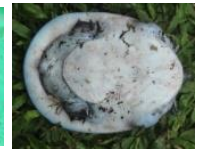

(d)

Figure 6. Dogania subplana: male carapace (a), male plastron (b), female carapace (c) and (d) female plastron (source: Personal documentation)

\section{Identification and Description of Orlitia borneensis}

Orlitia borneensis is known by the name biuku, dress, or ivory turtle. The Conservation Status of Orlitia borneensis according to IUCN is Critically endangered. According to PP. 7 of 1999 Orlitia borneensis is a protected species. Byuku's tortoise has an oval and smooth carapace that is blackish or dark brown (Figures 7a and 7c). Plastron is white or cream in color without the presence of certain spots. The hidden skin was creamy and slightly gray (Figs. 7b and 7d).

The head is relatively large, dark gray without any spots or lines. Its legs and upper neck and tail are dark gray or blackish.

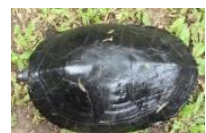

(a)

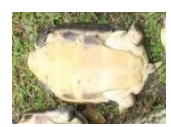

(b)

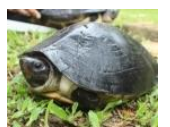

(c)

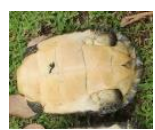

(d)

Figure 7. Orlitia borneensis: male carapace (a), male plastron (b), female carapace (c) and (d) female plastron (source: Personal documentation)

\section{Identification and Description of Notochelys platynota}

Notochelys platynota is known as the flatbacked turtle. Conservation status according to IUCN is categorized as vulnerable, while according to CITES it is included in Appendix II, namely species that are not threatened with extinction but will experience extinction if their use is not controlled or excessively. Notochelys platynota is characterized by an elongated shell shape, the adult carapace is brown, with spots (Figures $8 \mathrm{a}$ and $8 \mathrm{c}$ ). The plastron is yellow to brown in color, the belly is red (Figures $8 \mathrm{~b}$ and $8 \mathrm{~d}$ ).

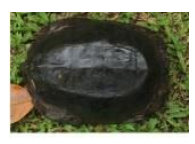

(a)

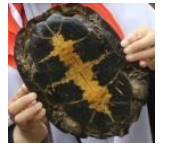

(b)

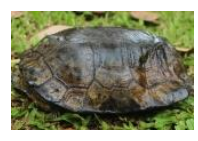

(c)

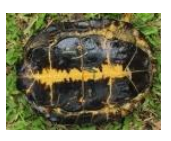

(d)

Figure 8. Notochelys platynota: male carapace (a), male plastron (b), female carapace (c) and (d) female plastron (source: Personal documentation)

The head is brown brown with yellow stripes on the pups (disappear as adults). The male has a slightly sunken belly and a longer tail while the female has a flat belly and a shorter tail.

\section{Identification and Description of Siebenrockiella crassicollis}

Siebenrockiella crassicollis is known as white cheek turtle. Conservation status according to CITES white cheek turtles are listed in the CITES appendix II list and according to the IUCN 
in the Vulnerable category this is due to changes and loss of their natural habitat as well as the pressure of fishing in nature to be traded.

The characteristics of a white-cheeked turtle are white or pale patches on the cheeks and above the eyes. The carapace is black (Figures 9a and 9c), plastron is brownish black and has a yellow spot in the center (Figures 9b and 9d).

Its head is pitch black. On his head there is a large white spot behind his eye. Another white spot is above the eye on the upper jaw and the corner of the mouth is relatively small.

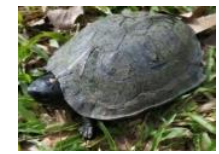

(a)

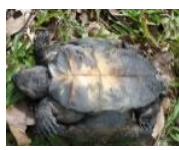

(b)

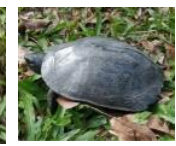

(c)

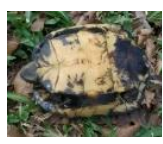

(d)

Figure 9. Siebenrockiella crassicollis: male carapace (a), male plastron (b), female carapace (c) and (d) female plastron (source: Personal documentation)

\section{Validation of the Due Diligence Module by the Validator}

From the results of the validation by four biology lecturers as validators, it was obtained that the module assessment was "very feasible". Validation Modules are assessed using a validation sheet. The results of the validation and suggestions from the validator are presented in Table 2.

Table 2. Results of Validation Data Calculation by Validators

\begin{tabular}{|l|l|l|l|}
\hline No & Validator & Persentase & Kriteria \\
\hline 1 & Ahli Materi & $86,53 \%$ & Sangat Layak \\
\hline 2 & Ahli Media & $91,67 \%$ & Sangat Layak \\
\hline
\end{tabular}

Based on the validation assessment by the material expert validator, the score was 89 and the average was 44.5 and with a percentage of $88.23 \%$ in the "Very Appropriate" category. And validation by the media expert validator got an assessment of a score of 66 and a mean of 33 with a percentage of $91.67 \%$ in the "Very Appropriate" category.

To achieve this score, it has been revised several times because there are still aspects that need to be improved. According to Prastowo (2013), there are five characteristics of the Module. First, the module is the smallest and complete teaching unit. Second, the module contains a series of planned and systematic learning activities. Third, the module contains explicit and specific learning objectives. Fourth, the module allows students to learn on their own, because the module contains self-instructional material. Fifth, the module is the realization of the recognition of individual differences, that is, one of the manifestations of individual teaching.

Based on the research, the module that has been made meets the characteristics of the module according to the expert. This is because the Sumatran turtle Diversity E-Module can measure the achievement of student learning goals with the embodiment of individual teaching. Judging from the acquisition of cognitive results of students who reached $80 \%$ with an average value of 85 .

\section{CONCLUSION}

There are 5 types of Sumatran turtles in the Turtle Learning Center (TLC) Conservation area of Bengkulu University, namely Heosemys spinosa, Cuora amboinensis, Cyclemys dentata, Siebenrockiella crassiocollis, Notochelys platynota, Manouria emys and those in the conservation 
area of Life Science Learning Resources (SBIH) are Dogania subplana, Pelochelys cantorii, Notochelys platynota, Manouria emys, and Ortilia borneensi. These include soft-shell turtles (Dogania subplana and Pelochelys cantorii) and 7 hard-shell types (Heosemys spinosa, Cuora amboinensis, Cyclemys dentata, Siebenrockiella crassiocollis, Notochelys platynota, Manouria emys, Ortilia borneensis). The results of the validation by four validators of Biology Lecturers on the Sumatran Tortoise Diversity E-Module received the "Very Appropriate" category, namely 86.53\% Material Experts and $91.67 \%$ Media Experts.

\section{REFERENCES}

Daryanto. (2013). Menyusun Modul Bahan Ajar Untuk Persiapan Guru dalam Mengajar. Yogyakarta: Gava Media.

Iskandar, D.T. (2000). Kura-Kura dan Buaya Indonesia \& Papua Nugini. Bandung: PALMedia Citra.

Kendrick, R.C \& Ades, G.W. (2009) Taxonomic and Morphometric Analysis of a Trade Confiscation of Turtle Shells from Java, Indonesia. Turtle Log, 4, 1-4.

Kemenhut. (2012). Lembaga Konservasi. http://lpp.dephut.go.id/downlot.php?file= 1393595147_1393595151.pdf accessed on June 2020 .

Khoyati F. (2016). Pengembangan Modul Matematika Untuk Pembelajaran Berbasis Masalah pada Materi Pokok Persamaan Garis Lurus Kelas VIII SMP. Jurnal Universitas Negeri Sebelas Maret Surakarta, 4(7), 608-621.

Kursini, M.D dan Yazid, M. (2005). Kura-kura Asia dalam Krisis dalam Warta Herpetofauna edisi 3. Bogor: ITB.

Melati. (2012). Kamus Biologi. PT. Aksara Sinergi Media. Surakarta

Oktaviani D, Andayani N, Kusrini MD \& Nugroho D. (2008) Identifikasi dan Distribusi jenis Labi-labi (Famili: Trionychidae) di Sumatera Selatan. Jurnal Penelitian Perikanan Indonesia, 14(2), $145-157$.

Prastowo. (2013). Panduan Kreatif Membuat Bahan Ajar Inovatif. Yogyakarta: Diva Press.

Zukmadini, A.Y, Wiryono, Aceng R dan Catherine M. (2017). Pengetahuan Konservasi Pada Siswa SMA dengan Pembelajaran Indoor-Outdoor Menggunakan Modul Pendidikan Konservasi Kura-kura. Dipresentasikan Pada SEMIRATA Wilayah Barat Bidang MIPAJambi. 